\title{
The Effectiveness of a Model of Language-Focused Classroom Instruction on the Vocabulary and Narrative Development of Kindergarten Children
}

\author{
DIANE CORCORAN NIELSEN, UNIVERSITY OF KANSAS, LISA DINNER FRIESEN, NORTH KANSAS CITY PUBLIC \\ SCHOOLS, AND JUDY FINK, KANSAS CITY PUBLIC SCHOOLS
}

\section{ABSTRACT}

The purpose of the study that is reported in this article was to examine the effectiveness of a model of language-focused instruction, delivered by the classroom teacher, on the vocabulary and narrative development of kindergarten children living in high-poverty conditions. There were 22 participants, the majority significantly behind their peers on standardized measures of vocabulary and narrative (understanding and production). The four-day sequence of instruction focused on a different storybook each week for 12 weeks. The findings demonstrated that it was possible to increase both vocabulary and narrative with explicit classroom instruction, repeated experiences, and active engagement. Implications for core kindergarten instruction and for teacher education are discussed.

Many children who live in poverty in urban areas of the United States enter school with home language and literacy experiences that lead to them to be viewed as "behind" their mainstream peers Historically, large numbers of these children were placed inappropriately in lower academic tracks, special education settings, or remedial programs because their knowledge and language were different from those that are required in a school setting (Delpit, 1995). Research studies (Klingner et al., 2005) and federal reports (National Research Council, 2002) have confirmed the disproportionate representation of minority students in special education programs. This problem was addressed in the reauthorization of the Individuals with Disabilities Act (IDEA) (2004), and in one of the final regulations, the act required that local educational agencies and states institute policies and procedures to prevent inappropriate identification (United States Department of Education Office of Special Education Programs, 2007). At the same time, informed thinking about students with reading difficulties resulted in a shift from a "wait to fail" model to prevention through "Response to Intervention" (RTI) (Fuchs \& Fuchs, 2006). This comprehensive approach to instruction is multi-tiered, and begins with exemplary, evidence-based "core" classroom reading instruction for all students (commonly referred to as Tier 1). Typically, beginning in kindergarten, children are screened on aspects of reading, with a focus on code-related tasks (e.g. , letter recognition and phonemic awareness), to determine if they need additional (Tier 2) support. If a student does not make gains following Tier 1 and 2 instruction, more intense intervention (Tier 3) is provided. Although considerable research has been published on interventions (e.g., Simmons et al., 2008; Vadasy, Sanders, \& Peyton, 2006; Vellutino, Scanlon, Small, \& Fanuele, 2006), particularly on code-based skills, research on "core" or classroom instruction is lacking.

If the goal is an appropriate core and intervention classroom curriculum beginning in kindergarten, then a full understanding of long-term reading achievement should guide the development of such curricula. Based on extensive research, we know that letter knowledge, phonemic awareness, and basic decoding skills are critical to success in beginning reading (Adams, 1990; National Reading Panel, 2000). However, these "basics" alone will not make a skillful reader; rather it is early oral language competencies that promote achievement in reading, if reading is defined as skillful comprehension (Snow \& Dickinson, 1991). The strong relationship between children's language development when they begin school and their later reading comprehension is clearly supported in the literature (Catts, Bridges, Little, \& Tomblin, 2008; Dickinson \& Tabors, 2001; National Institute of Child Health and Human Development [NCHD], 2005; Scarborough, 2003; Storch \& Whitehurst, 2002).

In a recent study of 17,219 kindergarten students from across the country Hair, Halle, Terry-Humen, Lavelle, and Calkins (2006) found that nearly one-fourth of all kindergarteners enter school with language development behind their age mates. Children of poverty disproportionally carry this "risk" profile. Whether halfday or full day, the core instruction in a kindergarten is the primary source of instruction for these students, and the curriculum should be designed to support all elements of reading, not just the code-based elements that are typically the focus. In addition, due to the reality of urban school settings, where extra staff for small group or intervention instruction is uncommon, it is important to investigate the effects of core instruction that focuses on the language-related aspects of reading

In this article we report and discuss the findings of a study conducted with high-poverty, urban kindergarten children who as a group were significantly behind their peers on standardized measures of language development. The authors investigated the effect of an instructional framework, delivered to the whole group, on the students' vocabulary and narrative development. A major premise of the study was that, while high-quality instruction in the basics of reading (phonemic awareness, letter identification, word-recognition strategies) is essential to supporting students' initial success as readers, this curriculum is not adequate for their long-term reading achievement (Tabors, Snow, \& Dickinson, 2001). 


\section{BACKGROUND}

\section{Language Development and Comprehension}

There is evidence to suggest that instruction in reading comprehension strategies can lead to improvement (Pressley, 2000); however, research also indicates that language development is at the heart of comprehension and explains the difficulties many students experience (Catts, Adolf, \& Weismer, 2006; Dickinson \& Tabors, 2001; Scarborough, 2003). The relationship between language development and reading comprehension has been validated across all socioeconomic groups but is particularly relevant to children of poverty. Hart and Risley (1995) found that by age 3, the vocabulary development of poor children was significantly behind their peers in other socioeconomic groups. Snow and her colleagues investigated the effect of a child's language development on later reading achievement in two longitudinal studies. In the initial study (Snow, Barnes, Chandler, Goodman, \& Hemphill, 1991) the researchers followed children in their homes and schools in grades 2, 4, 6, and subsequently followed them in high school. In the second study, children were followed from preschool through seventh grade (final report: Dickinson \& Tabors, 2001). In both studies the researchers found that a child's receptive vocabulary and decontextualized language, including narrative, significantly affected later reading achievement. Catts and colleagues (2008) followed 604 children from kindergarten through high school and found that subjects with language-comprehension problems in early grades were at even greater risk for reading comprehension problems in higher grades. Such studies inform our understanding of why children who may do well in early basic reading tasks fall behind in comprehension as the required texts become more complex. The National Institute of Child Health and Human Development (NICHD) Early Childhood Research Network (2005) conducted a longitudinal study of 1,137 children from age 3 through grade 3 to investigate the influence of comprehensive language skills (vocabulary, grammar, and semantics) and found that these skills were indirectly and directly related to first-grade word recognition and third-grade comprehension for children from both the higher and lower SES groups. The authors concluded that while instruction in phonological awareness and vocabulary was important, if these skills were not augmented, the curriculum "will prove too narrow to support academic achievement" (p. 440).

The instruction in this study focused on infusing language and opportunities to talk into the curriculum, with books as central to the instruction in vocabulary and narrative, two critical aspects of language related to later reading achievement.

\section{Vocabulary}

The relationship between students' vocabulary knowledge at a young age and reading comprehension is well documented (e.g., Cunningham \& Stanovich, 1997; Tabors et al., 2001), but as has been noted, some children come to school with very limited vocabulary (Hart \& Risley, 1995). Biemiller and Slonim (2001) studied the root vocabulary knowledge of a normative sample of children within a wide socioeconomic range and an advantaged sample in kindergarten through grade 5 . The authors estimated the root word vocabulary of first graders in the lowest quartile of the normative population to be 1,122 words, compared to the mean number of the larger population $(2,669)$ and the highest quartile of the normative population $(4,030)$. It was not until fourth grade that the lowest-quartile students in the normative population knew approximately the same number of words $(4,293)$ as the first graders in the highest quartile. Expectedly, their grade peers knew many more words (mean for the normative population in grade $4: 6,794)$. The need for vocabulary instruction is clear from this study and others; however, little attention has been given to vocabulary instruction in preschools or early grades (Baumann, Kame'enui, \& Ash, 2003; Neuman \& Dwyer, 2009).

While these findings cause concern, in recent years, a number of studies have been published on vocabulary instruction as a part of or outside the context of book interaction, or in combination (e.g., Beck \& McKeown, 2007; Biemiller \& Boote, 2006; Coyne, McCoach, Loftus, Zipoli, \& Kapp, 2009; Justice, Meier, \& Walpole, 2005; Silverman, 2007; Silverman \& Crandell, 2010). Biemiller and Boote's (2006) review of the research on using books to teach vocabulary revealed that repeated readings with word-meaning explanations resulted in the highest gains. The element of elaborating or explaining word meanings when teaching new vocabulary has continued to be embedded into the instructional frameworks of more recent studies. For example, Coyne and his colleagues (2009) compared three methods for directly teaching vocabulary to kindergarteners varying the time and depth of instruction that was provided during read-aloud time as well as extensions that occurred at other times in the day. They found that while students could develop partial knowledge of words through embedded attention within storybook reading (breadth), fuller word knowledge (depth) occurred with extended instruction through discussion and interactions with the words outside the storybook reading.

Addressing the reality that the vocabulary knowledge of young children can vary widely (Hart \& Risley, 1995), some studies have examined the effect of particular instructional practices on the vocabulary learning of students with lower-and higher-levels of vocabulary knowledge. Connor, Morrison, and Slominski (2006) spent a year observing 156 preschool children taught by one of 25 different teachers and found that all children made gains in vocabulary in classrooms where they engaged in meaning-based activities. However, examining data by level of vocabulary knowledge, they found that children who entered school with a low level of vocabulary knowledge made greater gains in classrooms where they engaged in "Teacher/Child Managed" (TCM) meaning-based activities (e.g., interactions with books and dramatic play), rather than code-focused activities. Children with higher levels of vocabulary knowledge made greater vocabulary gains "when they spent more time in TCM meaning-focused activities and more time in TCM code-focused activities" (p. 679). Silverman and Crandell 
(2010) also examined the effect of the level of children's vocabulary knowledge at school entrance. They conducted a yearlong observational study of the vocabulary-related instructional practices of preschool and kindergarten teachers during and outside the context of read-aloud time and the effect on vocabulary as assessed by norm-referenced and curriculum-based measures. The authors found that while some practices (word study) affected the vocabulary growth of all children in both settings, other practices affected vocabulary learning differently in the two settings (read aloud and non read aloud) and for the two different groups of students (initial level of vocabulary knowledge, higher vs. lower). For example, the practice of acting out and illustrating word meanings during read-aloud time supported the vocabulary growth of the lower-level students, but negatively affected the vocabulary growth of the higher-level group. Applying words in new contexts during non-read-aloud time affected the vocabulary growth of all students, but "greater use of this practice was related to greater gains in vocabulary for children with higher vocabulary knowledge" (p. 334).

These studies suggest that instructional practices can affect a child's vocabulary knowledge, and as reviewed previously, this knowledge affects later reading comprehension. A young child's understanding of story is another element that predicts later reading comprehension and can be developed through instruction.

\section{Narrative}

Story schema research (e.g., Mandler \& Johnson, 1977; Trabasso \& van den Broek, 1985) suggests that experiences with stories help children to develop an internalized framework that assists in understanding and remembering new stories. Knowledge of story structure, reflected in retellings, influences comprehension (Catts et al., 2006; Dickinson \& Tabors, 2001). Applebee (1978) studied the development of the child's sense of story and found that the level of understanding affected the ability to make sense of new stories. Stadler and Ward (2005) proposed a five-level continuum of storytelling development and suggested that support can influence progress: "A child will likely relate two or even three narrative levels at any age, but with support move to higher levels." (p. 79). In addition, researchers have found that knowledge of the structure of stories, as reflected in retellings, influenced later reading comprehension (Catts et al., 2008; Dickinson \& Tabors, 2001; Lynch \& van den Broek, 2007). The extensive work of van den Broek and his colleagues over the past 30 years has revealed that even preschool children are sensitive to the causal structure or cause/effect connections between events in stories. This sensitivity, which increases with age, was evident in the finding that when stories were heard or read, readers remembered those elements of the story (e.g., characters' goals and attempts to reach their goals) that had more causal connections (van den Broek, Kendeou, Lousberg, \& Visser, 2011). This is an important consideration when planning instruction.

Expression of narrative understanding has been found to be affected by cultural differences in experiences with narrative and storytelling style (Vernon-Feagans, Hammer, Micco, \& Manlove, 2001). After studying the role of culture in storytelling and narrative development, McCabe (1997) concluded, "These effects occur not only because of differences in how people tell stories but also because the way people tell stories affects their comprehension of stories from traditions other than their own" (p. 462). While recognizing that a child's score on a narrative assessment task may be due to unfamiliarity with the task rather than a deficiency (Gutierrez-Clennan \& Pena, 2002), it is appropriate to actively facilitate children's narrative development (Fillmore \& Snow, 2002) since such understanding will support later reading comprehension. Although research suggests that children who were disadvantaged due to poverty did less well on narrative tasks than their higher-income peers (Tabors et al., 2001; Vernon-Feagans et al., 2001), studies of parent/child book-sharing interventions demonstrate that low-income parents can affect children's narrative production (Peterson, Jesso, \& McCabe, 1999; Tabors et al., 2001). Classroom teachers can be influential as well.

Reenacting and retelling stories in classrooms can facilitate the development of narrative in young children. Pellegrini and Galda (1982) engaged K-2 children in drawing, adult-led discussion, or thematic fantasy play (reenactment) following the reading of a story. The results indicated that reenactment significantly affected story comprehension. Nielsen (1993) found similar results in her study of group interaction with storybooks on the literacy growth of low achieving kindergarten children. Silvern, Taylor, Williamson, Surbeck, and Kelly (1986) found that with or without adult guidance, children recalled reenacted stories better than stories they only discussed. In studies where students were given guidance and an opportunity to practice retelling stories, the number of story elements included in retellings increased, and significant differences were found in story comprehension compared to students who did not engage in retelling (Morrow, 1986; Nielson, 1993).

\section{PURPOSE AND METHODS}

The purpose of the study was to investigate the effects of languagefocused instruction on the vocabulary and narrative development of kindergarten children who live in high-poverty conditions. The study was conducted in a Midwestern, urban school where $80.5 \%$ of the children qualified for free or reduced lunch. Students participated in 30-minute lessons four days each week for 12 weeks, provided by the classroom teacher, who at the time of the study had 27 years teaching experience in either kindergarten or first grade. Students' growth on language assessments was examined within group following the end of the instruction.

\section{DATA COLLECTION AND SCORING}

The researchers collected both standardized and non-standardized assessment data to determine the effect of the classroom instruction on students' progress in aspects of language, specifically narrative development and vocabulary. Although the Test of Oral Language Development (TOLD) (Newcomer \& Hammill, 1997) 
yielded a full language composite (semantic and syntactic), we also administered semantic subtests (picture vocabulary, relational vocabulary, oral vocabulary) before and after the intervention and used each student's NCE score on the semantic composite in our analysis. The manual reported high reliability:

... average alphas for the subtests and composites are all highly acceptable. All of the coefficients for the subtests equal or exceed .80; in seven of nine instances they round to 90 . Coefficients for the composites are all greater than .90. (p. 56)

Because one focus of the study, narrative development, was not assessed by the TOLD, the researchers also administered the Test of Narrative Language (TNL) (Gillam \& Pearson, 2004), a standardized assessment with subtests of Narrative Comprehension (understanding) and Oral Narration (production of narratives). This test was normed on a nationally representative sample (by gender, race, ethnicity, and language disorder) of children ages 5 to 11. Analyses for internal consistency found an average of .88 for the coefficients of the TNL composite scores across age groups; coefficients ranged from good to excellent on test-retest Narrative Comprehension and Oral Narration. Interscorer reliability for Narrative Comprehension was .94, and for Oral Narration, 90. Narrative production portions of the TNL were taped and transcribed before scoring, and manual guidelines were followed for scoring the TOLD and TNL. In addition, data were gathered on researcher-created assessments of vocabulary and narrative.

A vocabulary assessment of target words from the 12 storybooks was developed for the study. Words were chosen based on their frequency in the books, and whether they could be to be categorized as Tier Two words, high-frequency words that "can add productively to an individual's language ability" (Beck, McKeown, \& Kucan, 2002, p. 16). As these authors suggest, "One 'test' of whether a word meets the Tier Two criterion of being a useful addition to students' repertoires is to think about whether the students already have ways to express the concepts represented by the words" (p. 16). To select words for assessment and instruction, the first author (a reading researcher), a graduate research assistant (GRA), and a professor with expertise in language development listed possible words from the books that fit Beck et al.'s guidelines. We kept in mind our knowledge of the vocabulary typically used by this high-poverty student population to "test," as Beck and her colleagues suggested, the potential of a word for selection. After our lists were generated we narrowed the selection to seven words per book for books 1-6 (42 words) and six words per book for books 7-12 (36 words). Appendices A and B provide a bibliography of the books and a list of selected vocabulary.

The first author developed the vocabulary assessment using guidelines modified from Justice and colleagues (2005) to yield a score of 0,1 , or 2. (See Appendix C.) A researcher and a GRA scored the vocabulary pretest for books 1-6 using the scoring rubric until agreement was reached. For all other data points (1-6 post, delayed post for books 1-6, pre and post for books 7-12), five of the 22 were selected randomly and scored by both the researcher and GRA with $93 \%, 94 \%, 95 \%$, and $93 \%$ inter-rater reliability, respectively. The remaining tests were scored by the GRA.

The students' ability to retell stories was assessed following the first week of instruction (baseline), as well as during Weeks 4, 8, and 12. A GRA followed a protocol for collecting audiotapes of the children retelling the story that had been used in the previous week for instruction. Collecting and analyzing retellings is a commonly accepted means of assessing the narrative understanding of young children (Skarakis-Doyle \& Dempsey, 2008). The retellings were transcribed and scored on a rubric based on the work of Trabasso and van den Broek (1985) (see Appendix D). The retelling rubric was categorized by narrative story elements: setting, initiating event, characters, characters' goals, their attempts to meet their goals, and outcome. For each story, scoring requirements were established for goals and attempts based on the number in the story. Points possible (10) were always the same, however, the requirements were adjusted to account for stories with more goals or attempts. Four of the Week 1 retellings were scored by the reading researcher and the GRA until they reached agreement. Nine $(50 \%)$ of the 18 remaining Week 1 retellings were scored with $100 \%$ inter-rater reliability. The final Week 1 retellings were scored by the GRA. For both Weeks 4 and 8 , the reading researcher and the GRA scored all the retellings by coming to agreement. Week 12's retellings were scored the same as the first set of retellings with $95 \%$ interrater reliability for the nine scored independently. The remaining nine were scored by the GRA.

A GRA collected all the data in one-to-one settings. The preassessments (TOLD semantic composite, TNL, vocabulary for all books) were collected in early January prior to the instruction. Post-testing of the students' knowledge of the vocabulary taught in books 1-6 was conducted in Week 7. Post-tests of the original assessments (TNL, the TOLD semantic subtests only, vocabulary post 7-12 and delayed post 1-6) were administered in lateApril/early-May following the conclusion of the instruction.

\section{Participants}

The 22 participants, nine (41\%) girls and $13(59 \%)$ boys were members of one full-day kindergarten class. The diversity of the school was reflected in the students in this class: African American, $11(50 \%)$, Hispanic $4(19 \%)$, Caucasian $6(22 \%)$, and Asian 1 (5\%). Three students (14\%) were English Language Learners. While representing a range of language abilities, a large percentage scored one or more standard deviations below the mean on the standardized measures of language development, specifically, 9 $(41 \%)$ on the semantic composite pretest of the TOLD (Newcomer \& Hammill, 1997) and $14(84 \%)$ on the Test of Narrative Language (Gillam \& Pearson, 2004).

In addition, the classroom teacher was interviewed three times by a GRA (after Week 3, Week 6 , and Week 12) to discuss her perceptions of the lesson structure, the way the instruction worked for her and the students, and the modifications she made to the lesson structure to accommodate her classroom. 


\section{Instruction}

The instruction focused on a different children's book each week for 12 weeks and took approximately 30 minutes per lesson. Prior to the study, the teacher used this 30-minute block of time for reading a book aloud once or twice and the remainder of the time for discussion. On occasion, she created an interactive writing chart (Button, Johnson, \& Furgerson, 1996) related to the story, such as listing the characters in order to engage the students in applying what they had learned about using sounds and letters to write words.

Since one aspect of the study focused on the development of narrative (understanding and production), book selection was based on narrative structure and informed by the research on the elements students remembered as they processed narrative (Trabasso \& van den Broek, 1985): characters' goals, attempts to reach goals, and outcomes. Additional considerations were length (could be read in six to eight minutes), appeal to children of kindergarten age (e.g., animal characters, humor, satisfying ending), and potential for learning new vocabulary, Tier Two words as defined by Beck and McKeown (2007). Swimmy (Lionni, 1963) is an example of a wellknown story that met these criteria. The instructional principles of the two components and an overview of how these components were scheduled into each day are described in the next section.

A researcher met with the teacher before the study began and gave her the books and general guidelines for using them (see Appendix E), a page of specific information for each book (definitions for the vocabulary words and comprehension questions focused on story elements), photos representing the vocabulary words, 10 extra copies of each book, and five sets of laminated "puppets" to support the retelling component.

Procedures and observations: The vocabulary component. As noted previously, six or seven vocabulary words were taught with each book. Definitions used for the target words were preplanned and written in child-friendly terms. On Day 1, following the first reading of the book without showing the pictures to the children (Beck \& McKeown, 2001), three vocabulary words were taught explicitly with the teacher providing the context as appropriate (Cummins, 2000). For example, there were photos for all words (obtained from Google Images). Context was provided also through actions for verbs such as "sighed" and "swaying," and concrete objects for nouns, such as "sack" and "mug." Words with similar meanings, such as "grimy" and "dust," were taught on separate days to help students distinguish between them, but words that could be contrasted easily were taught on the same day. After introducing the first three words, the teacher read the book again, showing students the pictures, and instructing them to "listen for our new words." At the end of the Day 1 lesson, the vocabulary was reviewed briefly, and the teacher showed the photos and/or provided another form of context.

On Day 2, the previous day's words were reviewed, and the remaining three or four vocabulary words were taught explicitly. Review was provided in various ways. The reading researcher also provided the teacher with basic guidelines (Beck et al., 2002) to facilitate independent expansion of the lesson. For example, to engage the students in providing examples of some of the target words, prompted sentences were planned for practice/review (for example, "A___ is a creature."). Words from previous books were reviewed and reinforced during the narrative component activities (acting out and retelling), as appropriate. Additionally, on Days 3 and 4 , all vocabulary was reviewed in a variety of ways, including reading a sentence from the book and asking students to explain the meaning to their partners, or saying a vocabulary word and asking students to share a real-life example. In an interview, the teacher reported that whenever possible, she included the project vocabulary in other content areas. For example, in mathematics the target word "bunch" was incorporated into the discussion of making groups of 10 . Students were praised if they used the vocabulary words on their own. The teacher reported that she occasionally heard students using the target vocabulary outside of the lessons. For example, in the first interview, she noted overhearing a student on the playground mentioning to another child that her hands were "grimy," a word introduced during the first week's book. The teacher noted that students also identified project vocabulary words encountered in other stories read by the teacher. In another interview, the teacher reported that students noted that the setting of two non-project books was a "forest." The teacher also reported that students commented that both a character is a non-project book and a child in the class were "clever," and in both instances were able to explain why.

Procedures and observations: The narrative component. Narrative understanding and production was emphasized in multiple ways across the four-day lesson structure: purpose setting prior to reading and preplanned questions focusing on story elements (Day1), review of story elements and participation in story reenactment (Day 2), and story retelling using various supports: the book's pictures (Day 2), chart (Days 3 and 4), tag-board puppets (Day 4). Before the book was read on Day 1, the teacher showed the students the cover; introduced the setting and characters; and stated a purpose for listening, based on key story elements (Trabasso \& van den Broek, 1985). The teacher read the book initially without showing students the pictures. Beck and McKeown (2001) demonstrated that children pay more attention to the language of the book when they are not shown the pictures. At the end of that reading, the teacher returned to the previously set purpose and focused a quick discussion on key story elements. Following the second reading (during which the pictures were shown), the teacher asked the students preplanned questions focused on story elements (Trabasso \& van den Broek, 1985).

On Day 2, instead of reading the book, the teacher guided the students through a group retelling of the story by showing each page and focusing on the story elements. In an interview, she noted that this retelling allowed children who were absent on Day 1 to learn the story. Next, the children participated in story reenactment. While the researcher originally suggested that the teacher conduct the story reenactment component as in a previous 
study (Nielsen, 1993), engaging all the students in acting out the story, the teacher created her own activities. She reported that rather than retelling/narrating herself, after the first week or so, she began to ask for volunteers. As the weeks progressed, more children volunteered, and the teacher prompted the children as they enacted the story and prompted the narrator as needed, consistently attempting to keep everyone actively engaged.

On Day 3, the narrative-related goal was to chart a short story, a teacher-guided retelling, by prompting the class to tell what happened by calling on a variety of students. The typical chart followed a format that yielded five pages: the title page, the beginning of the story, the middle (two pages), and the last part of the story. For several weeks, the teacher used three marker colors to symbolize the beginning, middle, and end to cue different parts of the story. Child-sized duplicates of the chart were used for review and illustrated on Day 4.

Day 4 began with a review of the main story elements, followed by retelling with a partner using a copy of the book, then retelling using only cardstock puppets. After a quick review of the main story elements, the teacher guided the group through retelling, demonstrating with a copy of the book. Then the students retold the story several times, working with a partner and a copy of the book. The teacher first modeled turn taking and then directed partners to take turns telling the story using the pictures in the book. The teacher noticed that students initially tried reading the known words, rather than retelling the story in their own words. Repeated modeling and guided practice that focused on how to use the pictures in the book served as reminders because it was important for students to use their own words during the first several weeks while they learned how to retell a story.

The final activity of Day 4 was retelling the story without the book, prompted by laminated cardstock puppets made from copies of the book. The teacher found this component to be the most challenging, but reported in the second interview that she devised a solution by initially providing a model for the whole class using one set of puppet characters. Then, each child was given a puppet to move during the retelling; occasionally, students offered possible dialogue for their characters. When students no longer needed constant prompting and guidance, she formed four or five groups and gave each group the book and a set of puppets to use to retell the story, allowing her to monitor, prompt, and redirect as needed. As the weeks progressed, the groups required fewer prompts to complete the retelling. At the end of the week, the teacher placed a copy of the book and a set of puppets in the "Retelling Center" to be used alone or with a partner to retell the story during free choice and scheduled center time. The teacher reported that the children frequently chose to use these materials and often referred to the book to remind themselves or their partner of the story in an attempt to get the retelling "right." Since another retelling set was added to the center every week, more children were able to engage in retelling alone or with a partner. The teacher reported that this was such a popular activity that some children preferred it to recess.
Finally, either during the writing instruction block on Day 4 or on the last day of the week, the teacher reviewed the charted retelling that was created on Day 3 , discussing what could be drawn on that page of the students' 8 " $\times 10^{\prime \prime}$ facsimile of the chart. The students followed along using their own copy and drew an illustration, and the process was repeated with the next page. Once completed, the students were allowed to take these "books" home to retell the story in their own words. When communicating with parents about these little "books" and how to use them, the teacher reported that she asked the parents to engage their children in retelling not only those "books," but also, stories the parents read at home

\section{RESULTS AND DISCUSSION}

The findings of this study demonstrated that it is possible to increase both vocabulary and narrative understanding and production with explicit classroom instruction, repeated experiences, and active engagement.

\section{Vocabulary}

Using standard scores (NCE), t-tests were run to compare pre-topost test differences on a standardized measure related to vocabulary: the TOLD semantic composite. Significant differences were found: $t=2.21(1,21 \mathrm{df}) \mathrm{p}=.039$. The mean gains from pre-topost informal measures of vocabulary for the words taught explicitly for books $1-6$ and for books 7-12, as well as retention of vocabulary knowledge (delayed post) for the words taught in weeks 1-6 were calculated. Since it was the end of the school year, there was no time for a delayed posttest to be administered on the words from books for weeks 7-12. Table 1 presents a comparison of mean scores for both the TOLD semantic composite and the informal vocabulary assessment.

Gains on knowledge of the vocabulary words from the books were expected, since the words were taught explicitly with explanations and elaboration of word meanings as in previous research (Biemiller \& Boote, 2006; Justice et al., 2005). While the students were not directly taught the content of the semantic subtests of the TOLD semantic composite (Picture Vocabulary, Relational

Table 1. Vocabulary: Group Means (standard deviations) $(\mathrm{N}=22)$

\begin{tabular}{|c|c|}
\hline $\begin{array}{l}\text { TOLD-semantics composite } \\
\text { pretest (mean NCE) } \\
\text { posttest (mean NCE) }\end{array}$ & $\begin{array}{l}88.7(14.7) \\
94.7(12.8)\end{array}$ \\
\hline $\begin{array}{l}\text { Vocabulary gains (Books 1-6) } \\
\text { pretest } \\
\text { posttest } \\
\text { gain }\end{array}$ & $\begin{array}{l}15.9(7.6) \\
27.5(12.6) \\
11.6\end{array}$ \\
\hline $\begin{array}{l}\text { Vocabulary gains (Books 7-12) } \\
\text { pretest } \\
\text { posttest } \\
\text { gain }\end{array}$ & $\begin{array}{l}14.2(7.4) \\
25.8(10.4) \\
11.6\end{array}$ \\
\hline
\end{tabular}


Vocabulary, and Oral Vocabulary), as a group, they made statistically significant gains from pre-to-posttests. Given that the items on the TOLD subtests were not taught explicitly to the students, this is a noteworthy finding. It appears that the teacher's attention to words and her provision of opportunities to attend to words and word meanings carried over to gains on a standardized measure to a degree. A possible explanation for this finding is that the teacher made a point of not only attending to words during the book-related activities, but also outside the lessons. Coyne and his colleagues (2009) attributed fuller word knowledge (depth) to discussion and interaction outside of the storybook reading. There were numerous examples in all three interviews of ways the words and extensions of the words came into discussions, sometimes initiated by the teacher and other times by a student. The teacher also prompted students' accountability when they were asked to engage in partner review of words, or when she roamed and asked a child to relate what a partner had said. This attention to and accountability for discussions of words in different contexts may have heightened students' attention to words and added to their comfort with word-related tasks. Similarly, Silverman and Crandell (2010) found that engaging vocabulary in multiple ways had positive effects on the vocabulary learning of lower-level students. The literature on word consciousness (e.g., Graves \& Watts, 2002), suggests that teachers think beyond the goal of learning specific words to the potential effect of engaging students about what they know and can do with words. The teacher commented in an interview that she found her students almost consciously trying to find ways to use learned words in new contexts.

\section{Narrative}

The class mean on the TNL composite score was compared pre-topost intervention. Significant differences were found, $t=4.13(1$, $21 \mathrm{df}$ ) $\mathrm{p}=.000$ (mean scores: 77.1 pre and 90.2 post). Table 2 presents means and standard deviations. In terms of the nonstandardized measure of narrative understanding (retellings), data on all four retellings were available for 20 of the 22 students. The students made gains in their ability to retell stories from a group mean score of 3.7 (10 points possible) at the end of Week 1 to a class mean of 5.5 at end of Week 12. Table 3 presents a comparison of means.

Table 2. Narrative: TNL Composite Group Means (standard deviations) $(\mathrm{N}=22)$

\begin{tabular}{|l|l|}
\hline pretest (NCE) mean & $77.1(14.3)$ \\
posttest (NCE) mean & $90.2(14.9)$ \\
\hline
\end{tabular}

Table 3. Narrative: Retelling Group Mean Scores (standard deviations) $(\mathrm{N}=22)$

\begin{tabular}{|l|l|}
\hline Retelling 1 (Week 1 story) & $3.7(2.0)$ \\
Retelling 2 (Week 4 story) & $4.2(2.0)$ \\
Retelling 3 (Week 8 story) & $5.3(1.2)$ \\
Retelling 4 (Week 12 story) & $5.5(2.1)$ \\
\hline
\end{tabular}

The fact that students made gains in narrative is consistent with previous research (Nielsen, 1993; Pellegrini \& Galda, 1982), which found that repeated and active experiences with narrative, such as acting out and using puppets to support retellings, can affect students' demonstration of narrative understanding and production. While specific vocabulary can be taught explicitly, narrative is developed with repeated experiences with stories (Morrow, 1988; Senechal, LeFevre, Thomas, \& Daley, 1998). The gains on the TNL suggest that the repeated experiences with stories through attention to story elements, two readings of each book (one without showing pictures), response to story-elementrelated questions, story reenactment, and multiple experiences with guided group and partner retellings transferred to the students' narrative understanding and production, as assessed on the TNL (composite). The benefit of repeated and varied story-related experiences of the instruction also was evident in the gains the students made in their ability to produce more complete retellings over time (following instruction in Weeks 1, 4, 8, and 12), as presented in Table 3. A possible explanation for the gains in story retelling is that, to some degree, the teacher followed Pearson and Gallagher's (1983) explicit instructional model that incorporates a gradual release of responsibility from the teacher to the student. In this study, the teacher focused attention on the story elements related to the read aloud and questions. and attempted to model and provide guided and independent practice (in the center) in retelling with various supports (the book's pictures, guided retelling on the chart, cardstock puppets). In an essay on what teachers can do to support students' language development, Fillmore and Snow (2002) suggested, "Often explicit teaching of language structures and uses is the most effective way to teach learners" (p. 29). At the beginning of the study, considerable modeling was required for students to understand how to retell a story. Although modeling continued throughout the entire study, as the weeks went by, students took on more responsibility during the guided practice and independent practice phases of work with the books. While some students may develop story understanding by simply listening to books, we believe that the opportunity to actively engage in the stories was the key to the gains in narrative understanding and production for this population of high-poverty urban kindergarten students.

\section{Limitations and Implications for Future Research}

Limitations of this research include the fact that one teacher conducted the study in one classroom. In addition, this one teacher had a number of years of experience in kindergartens in high poverty, urban schools. She was given all the materials, such as extra copies of books for partner retelling, cardstock puppets, and photos to provide context for the vocabulary words.

These limitations provide directions for future research. For example, this instructional model could be studied with a larger sample of classrooms, including half-day kindergarten and with teachers who have varied levels of experience. Given that not all teachers would have access to the books used in this study or the 
materials prepared by the researchers (e.g., the vocabulary elements, comprehension questions, retelling materials), studies could be conducted that provide teachers with the principles of the vocabulary and narrative components and the schedule for the instructional model (e.g., Appendix E), as well as guidelines for selecting books and information on selecting target words and planning instruction. It also would be interesting to study this model for a full school year. In addition, one could examine a longer delay between the end of the 12 weeks of instruction and the follow-up testing (e.g., both a six-week and six-month delay) to determine whether students held their gains in narrative and vocabulary. Finally, many of the participants in this study were significantly behind their peers on standardized measures of language. While there were two students at or above the mean on these measures, the number of role models was limited. Fillmore and Snow (2002) stated that students learning language should be exposed to good models of the language. The teacher was the primary role model in this classroom. It would valuable to investigate the effect of this instructional model with a larger and more diverse sample, including students with a strong vocabulary and sense of narrative who could serve as role models to students with less-well developed vocabulary and narrative understanding and production.

Finally, full-day kindergarten is becoming more common. Research suggests that it has positive effects on the primary-grades reading achievement of low-income children, but the progress is not sustained (Lee, Burkam, Ready, Honigman, \& Meisels, 2006). If the classroom instruction provided in this study affected student language development in a short time, it holds promise for effective use of the extra time provided by whole-day kindergarten. It is important to explore further how to provide effective core instruction in aspects of language development in kindergarten due to its role in later reading achievement.

\section{Implications for Practice}

The results of this study also suggest implications for practice. Even though children who live in poverty commonly are significantly behind their middle- and high-income peers in vocabulary development (Hart \& Risley, 1995) and on other measures of language (NICHD, 2005), the findings demonstrate that it is possible to increase both vocabulary and narrative understanding with explicit classroom instruction, repeated experiences, and active engagement. Thus, it is possible to teach these aspects of language; it is imperative that teachers of young children provide this instruction. Fillmore and Snow (2002) noted that although teachers should understand and respect the discourse patterns and level of language proficiency a child brings to school, they also have a responsibility to provide instruction in the language used in books. "Teachers play a critical role in supporting language development. Beyond teaching children to read and write in school, they can help children learn and use aspects of language associated with the academic discourse of the various school subjects" (p. 12).

The findings of this study and the work of Fillmore and Snow (2002) suggest that the curriculum for both preservice and inservice teacher education should include attention to the responsibility of the teacher in language learning since language is so key to a child's long-term success as a reader. Given the relationship between aspects of language development, such as vocabulary and narrative understanding, to later reading achievement, attention to the aspects of language that were the focus of this study, rather the code-related aspects of reading alone, should become part of a comprehensive approach to instruction for all children in the early primary grades. Since classroom teachers provide this "core" instruction, they should be informed about how to "teach" aspects of language within the core curriculum as was done in this study, which infused explicit instruction and repeated experiences related to vocabulary and narrative. Teachers should also understand the multiple benefits of such instruction, including the ripple effect of attention to vocabulary on word recognition (Dickinson, McCabe, Anastasopoulos, Peisner-Feinberg, \& Poe, 2003; NICHD, 2005).

As Tabors and colleagues (2001) suggested at the conclusion of their longitudinal study with high-poverty children, "We fully expect that exposure to excellent schools and dramatically enriched language and literacy environments in the elementary years, whether at home or in school, could redirect a child's developmental pathway upwards" (p. 333). Classroom teachers can make that difference.

\section{References}

Adams, M. J. (1990). Beginning to read: Thinking and learning about print. Cambridge, MA: MIT Press.

Applebee, A. N. (1978). The child's concept of story. Chicago, IL: The University of Chicago Press.

Baumann, J. F., Kame'enui, E. J., \& Ash, G. E. (2003). Research on vocabulary instruction: Volaire redux. In J. Flood, J. Jensen, D. Lapp, \& J. R. Squire (Eds.), Handbook of research on teaching the English language arts (2nd ed., pp. 752-785). New York, NY: Macmillan.

Beck, I., \& McKeown, M.G. (2001). Capturing benefits of read-aloud experiences for young children. The Reading Teacher, 55(1), 10-20.

Beck, I., \& McKeown, M. G. (2007). Increasing young low-income children's oral vocabulary repertoires through rich and focused instruction. The Elementary School Journal, 107(3), 251-271.

Beck, I., McKeown, M. G., \& Kucan, L. (2002). Bringing words to life: Robust vocabulary instruction. New York, NY: Guilford.

Biemiller, A., \& Boote, C. (2006). An effective method for building meaning vocabulary in primary grades. Journal of Educational Psychology, 98(1), 4-62.

Biemiller, A., \& Slonim, N. (2001). Estimating root vocabulary growth in normative and advantaged populations: Evidence for a common sequence of vocabulary acquisition. Journal of Educational Psychology, 93(3), 498-520.

Button, K., Johnson, M. J. , \& Furgerson, P. (1996). Interactive writing in a primary classroom. The Reading Teacher, 49(6), 446-454.

Catts, H. W. , Adolf, S. M., \& Weismer, S. E. (2006). Language deficits in poor comprehenders: A case for the simple view of reading. Journal of Speech, Language and Hearing Research, 49(2), 278-293.

Catts, H. W., Bridges, M. S., Little, T., \& Tomblin, B. (2008). Reading achievement growth in children with language impairments. Journal of Speech, Language and Hearing Research, 51(6), 1569-1579. 
Connor, C. M., Morrison, F. J., \& Slominski, L. (2006). Preschool instruction and children's emergent literacy growth. Journal of Educational Psychology, 98(4), 665-689.

Coyne, M. C., McCoach, D. B., Loftus, S., Zipoli, R., \& Kapp, S. (2009). Direct vocabulary instruction in kindergarten: Teaching for breadth versus depth. The Elementary School Journal, 110(1), 1-18.

Cummins, J. (2000). Language, power and pedagogy: Bilingual children in the crossfire. Clevedon, UK: Multilingual Matters LTD.

Cunningham, A. E., \& Stanovich, K. E. (1997). Early reading acquisition and its relation to reading experience and ability 10 years later. Developmental Psychology, 33(6), 934-945.

Delpit, L. (1995). Other people's children: Cultural conflict in the classroom. New York, NY: New Press.

Dickinson, D. K., McCabe, A., Anastasopoulos, L., Peisner-Feinberg, E. S., \& Poe, M. (2003). The comprehensive language approach to early literacy: The interrelationships among vocabulary, phonological sensitivity, and print knowledge among preschool children. Journal of Educational Psychology, 95(3), 465-381.

Dickinson, D., \& Tabors, P. O. (Eds.). (2001). Beginning literacy with language. Baltimore, MD: Brookes.

Fillmore, L.W., \& Snow, C. E. (2002). What teachers need to know about language. In C.T. Adger, C. E. Snow, and D. Christian (Eds.), What teachers need to know about language (pp. 7-53). McHenry, IL: Center for Applied Linguistics and Delta Systems Company.

Fuchs, D., \& Fuchs, L. S. (2006). Introduction to Response to Intervention: What, why and how valid is it? Reading Research Quarterly, 4I(1), 93-99.

Gillam, R. B., \& Pearson, N. A. (2004). Test of Narrative Language. Austin, TX: Pro-Ed.

Graves, M. F., \& Watts, S. M. (2002). The place of word consciousness in a research-based vocabulary program. In S. J. Samuels \& A. E. Farstrup (Eds.), What research has to say about reading instruction (3rd ed., pp. 140-165). Newark, DE: International Reading Association.

Gutierrez-Clennan, V. F., \& Pena, E. (2002). Dynamic assessment of diverse children: A tutorial. Language, Speech, and Hearing Services in Schools, 32(3), 212-224.

Hair, E., Halle, T., Terry-Humen, E., Lavelle, B., \& Calkins, J. (2006). Children's school readiness in the ECLS-K: Predictions to academic, health and social outcomes in first grade. Early Childhood Research Quarterly, 2l(4), 431-454.

Hart, B., \& Risley, T. (1995). Meaningful differences in the everyday experiences of young American children. Baltimore, MD: Brookes.

Individuals with Disabilities Education Act, 20 U.S.C. Secs. 1400 et seq (2004).

Justice, L. M., Meier, J., \& Walpole, S. (2005). Learning new words from storybooks: An efficacy study with at-risk kindergarteners. Language, Speech and Hearing Services in Schools, 36(1), 17-32.

Klingner, J. K., Artiles, A. J., Kozleski, E., Harry, B., Zion, S., Tate, W., Duran, G. Z., \& Riley, D. (2005). Addressing the disproportionate representation of culturally and linguistically diverse students in special education through responsive educational systems. Education Policy Analysis Archives, 13(38). Retrieved from http://epaa.asu.edu /epaa/v13n38/.

Kurland, B.F., \& Snow, C.E. (1997). Longitudinal measurement of growth in definitional skill. Journal of Child Language, 24(3), 603-625.

Lee, V. E., Burkam, D. T., Ready, D. D., Honigman, J., \& Meisels, S. J. (2006). Full-day versus half-day kindergarten: In which program do children learn more? American Journal of Education, 112(2), 163-208.
Lynch, J. S., \& van den Broek, P. (2007). Understanding the glue of narrative structure: Children's on and off-line inferences about characters' goals. Cognitive Development, 22(3), 323-340.

Mandler, J. M., \& Johnson, N. S. (1977). Remembrance of things parsed: Story structure and recall. Cognitive Psychology, 9(1), 111-151.

McCabe, A. (1997). Cultural background and storytelling: A review and implications for schooling. The Elementary School Journal, 97(5), $453-473$.

Morrow, L. M. (1986). Effects of structural guidance in story retelling on children's dictation of original stories. Journal of Reading Behavior, 18(2), 135-152.

Morrow, L. M. (1988). Young children's responses to one-to-one story readings in school settings. Reading Research Quarterly, 23(1), 89-107.

National Institute of Child Health and Human Development Early Childhood Care Research Network. (2005). Pathways to reading: The role of oral language in the transition to reading. Developmental Psychology, $41(2), 428-442$.

National Reading Panel. (2000). Teaching children to read: An evidence-based assessment of the scientific research literature on reading and its implications for reading instruction. Washington, DC: National Institute of Child Health and Human Development.

National Research Council. (2002). Minority students in special and gifted education. Washington, DC: National Academy Press.

Neuman, S. B., \& Dwyer, J. (2009). Missing in action: Vocabulary instruction in Pre-K. The Reading Teacher, 62(5), 384-392.

Newcomer, P. L., \& Hammill, D. D. (1997). Test of Oral Language Development: Primary (3rd. ed.). Austin, TX: Pro-Ed.

Nielsen, D. C. (1993). The effects of four models of group interaction with storybooks on the literacy growth of low achieving kindergarten children. In D. J. Leu \& C. K. Kinzer (Eds.), Examining central issues in literacy research, theory, and practice (pp. 279-287). Forty-Second Yearbook of the National Reading Conference. Chicago, IL: National Reading Conference.

Pearson, P. D., \& Gallagher, M.C. (1983). The instruction of reading comprehension. Contemporary Educational Psychology, 8(3), 317-344.

Pellegrini, A. D., \& Galda, L. (1982). The effects of thematic-fantasy play training on the development of children's story comprehension. American Educational Research Journal, 19(3), 443-452.

Peterson, C., Jesso, B., \& McCabe, A. (1999). Encouraging narratives in preschoolers: An intervention study. Journal of Child Language, 26(1), 49-67.

Pressley, M. (2000). What should comprehension instruction be the instruction of? In M. L. Kamil, P. B. Mosenthal, P. D. Pearson, \& R. Barr (Eds.), Handbook of reading research, (Vol. III, pp. 545-561). Mahwah, NJ: Lawrence Erlbaum.

Scarborough H. S. (2003). Connecting early language to later reading (dis)abilities. In S. B. Neuman \& D. K. Dickinson (Eds.), Handbook of early literacy research (pp. 97-110). New York, NY: Guilford.

Senechal, M., LeFevre, J., Thomas, E., \& Daley, K. (1998). Differential affects of home literacy experiences on the development of oral and written language. Reading Research Quarterly, 33(1), 96-116.

Silverman, R. (2007). A comparison of three methods of vocabulary instruction during read-alouds in kindergarten. The Elementary School Journal, 108(2), 97-113.

Silverman, R., \& Crandell, J. D. (2010). Vocabulary practices in prekindergarten and kindergarten classrooms. Reading Research Quarterly, 45(3), 318-340. 
Silvern, S., Taylor, J., Williamson, P., Surbeck, E., \& Kelly, M. (1986). Young children's story recall as a product of play, story familiarity, and adult intervention. Merrill-Palmer Quarterly, 32(1), 73-86.

Simmons, D. C., Coyne, M. D., Kwok, O., McDonagh, S., Harn, B. A., \& Kame'enui, E. J. (2008). Indexing response to intervention: A longitudinal study of reading risk from kindergarten through third grade. Journal of Learning Disabilities, 4(2), 158-173.

Skarakis-Doyle, E., \& Dempsey, L. (2008). Assessing story comprehension in preschool classrooms. Topics in Language Disorders, 28(2), 131-148.

Snow, C. E., Barnes, W. S., Chandler, J., Goodman, I. F., and Hemphill. L. (1991). Unfulfilled expectations: Home and school influences on literacy. Cambridge, MA: Harvard University Press.

Snow, C. E., \& Dickinson, D. K. (1991). Skills that aren't basic in a new conception of literacy. In A. Purves \& E. Jennings (Eds.), Literate systems and individual lives: Perspectives on literacy and schooling (pp. 179-191). Albany, NY: SUNY Press.

Stadler, M. A., \& Ward, G. C. (2005). Supporting the narrative development of young children. Early Childhood Education Journal, 33(2), 73-80.

Storch, S. A., \& Whitehurst, G.J. (2002). Oral language and code-related precursors to reading: Evidence from a longitudinal model. Developmental Psychology, 38(6), 934-947.

Tabors, P. O., Snow. C. E., \& Dickinson, D. K. (2001). Homes and schools together: Supporting language and literacy development. In D. K. Dickinson \& P. O. Tabors (Eds.), Beginning language with literacy: Young children learning at home and school (pp. 313-334). Baltimore, MD: Brookes.

Trabasso, T., \& van den Broek, P. W. (1985). Causal thinking and the representation of narrative events. Journal of Memory and Language, 24(5), 612-630.

United States Department of Education Office of Special Education Programs. (2007, February 2). Topic: Disproportionality and overidentification. Retrieved from http://idea.ed.gov/explore/view/p/\%2Croot $\% 2$ Cdynamic\%2CTopicalBrief\%2C7\%2C.

Vadasy, P., Sanders, E., \& Peyton, J. (2006). Code-oriented instruction for kindergarten students at risk for reading difficulties: A randomized field trial with paraeducator implementers. Journal of Educational Psychology, 98(3), 508-528.

van den Broek, P., Kendeou, P., Lousberg, S., \& Visser, G. (2011). Preparing for reading comprehension: Fostering text comprehension skills in preschool and early elementary school children. International Electronic Journal of Elementary Education, 4(1), 259-268.

Vellutino, F. R., Scanlon, D. M., Small, S., \& Fanuele, D. P. (2006). Response to intervention as a vehicle for distinguishing between children with and without reading disabilities: Evidence for the role of kindergarten and first-grade interventions. Journal of Learning Disabilities, 39(2), 157-169.

Vernon-Feagans, L., Hammer, C. S., Micco, A., \& Manlove, E. (2001). Early language and literacy skills in low-income African American and Hispanic children. In S. B. Neuman \& D. K. Dickinson (Eds.), Handbook of early literacy research (pp. 192-210). New York, NY: Guilford.

\section{Children's Literature}

Lionni, L. (1963). Swimmy. New York, NY: Alfred A. Knoff, Inc.

\section{Authors' Note}

This study was supported in part by the University of Kansas Graduate Research Fund, grant number 2301111, and School of Education summer-research funds. Opinions expressed do not necessarily reflect the position of the University of Kansas.

Diane Corcoran Nielsen is an associate professor in the Department of Curriculum and Teaching at the University of Kansas. Professor Nielsen can be reached at dnielsen@ku.edu.

Lisa Dinner Friesen is a K-12 District Instructional Coordinator in the North Kansas City Public Schools. Dr. Friesen can be reached at lisadinner@gmail.com.

Judy Fink is a kindergarten teacher in the Kansas City Public Schools. Ms. Fink can be reached at kteacher64152@yahoo.com. 


\section{APPENDIX A. BIBLIOGRAPHY OF CHILDREN'S BOOKS}

Aylesworth, J. (1989). Mother Halverson's new cat. New York, NY: Macmillan Publishing Company.

Beck, I. (1989). Teddy Robber. London, UK: Random House Group Ltd.

Clements, A. (1988). Big Al. New York. NY: Aladdin Paperbacks.

De Beer, H. (1988). Ahoy there, little polar bear. New York, NY: North-South Books, Inc.

Kasza, K. (2001). The Mightiest. New York. NY: Puffin Books.

Kimmel, E. (1988). Anansi and the moss covered rock. New York. NY: Holiday House.

Lionni, L. (1963). Swimmy. New York: NY: Alfred A. Knoff, Inc.

Lord, J. L. (1972). The giant jam sandwich. Boston, MA: Houghton Mifflin Company.

Meddaugh, S. (1990). Tree of birds. Boston, MA: Houghton Mifflin Company.

Pryor, A. (1987). Baby blue cat and the dirty dog brothers. New York, NY: Viking Penguin Inc.

Sharmat, M. (1980). Gregory, the terrible eater. New York, NY: Scholastic, Inc.

Slobodkina, E. (renewed 1968). Caps for sale. New York, NY: HarperCollins Publishers. 


\begin{tabular}{|c|c|c|c|}
\hline $\begin{array}{l}\text { Baby Blue Cat } \\
\text { neighbor } \\
\text { neighborhood } \\
\text { grimy } \\
\text { sighed } \\
\text { floppy } \\
\text { paws } \\
\text { dust }\end{array}$ & $\begin{array}{l}\text { Caps for Sale } \\
\text { bunch. } \\
\text { town } \\
\text { trunk } \\
\text { country } \\
\text { sold } \\
\text { disturb } \\
\text { ordinary }\end{array}$ & $\begin{array}{l}\text { Swimmy } \\
\text { escaped } \\
\text { invisible } \\
\text { swaying } \\
\text { creatures } \\
\text { chased } \\
\text { lonely } \\
\text { waves }\end{array}$ & $\begin{array}{l}\text { Mother Halverson } \\
\text { barn } \\
\text { pantry } \\
\text { cream } \\
\text { evening } \\
\text { worried } \\
\text { agreed } \\
\text { timid }\end{array}$ \\
\hline $\begin{array}{l}\text { Anansi } \\
\text { path } \\
\text { yams } \\
\text { gather } \\
\text { wondered } \\
\text { inviting } \\
\text { tender } \\
\text { lazy }\end{array}$ & $\begin{array}{l}\text { Teddy Robber } \\
\text { sack } \\
\text { cupboard } \\
\text { mug } \\
\text { cuddled } \\
\text { slithered } \\
\text { sobbed } \\
\text { steep }\end{array}$ & $\begin{array}{l}\text { Gregory the Terrible Eater } \\
\text { horrible } \\
\text { fussy } \\
\text { munching } \\
\text { favorite } \\
\text { cardboard } \\
\text { necktie }\end{array}$ & $\begin{array}{l}\text { Big Al } \\
\text { seaweed } \\
\text { crowd } \\
\text { captured } \\
\text { dashed } \\
\text { floating } \\
\text { ocean }\end{array}$ \\
\hline $\begin{array}{l}\text { The Giant Jam Sandwich } \\
\text { field } \\
\text { dough } \\
\text { clever } \\
\text { feast } \\
\text { bait } \\
\text { swelled }\end{array}$ & $\begin{array}{l}\text { Ahoy There, Little Polar } \\
\text { Bear } \\
\text { ladder } \\
\text { deck } \\
\text { cheerful } \\
\text { ship } \\
\text { disappointed } \\
\text { net }\end{array}$ & $\begin{array}{l}\text { The Mightiest } \\
\text { crown } \\
\text { enormous } \\
\text { scoop } \\
\text { promise } \\
\text { peacefully } \\
\text { cliff }\end{array}$ & \begin{tabular}{|l|} 
Tree of Birds \\
frightened \\
heal \\
thermometer \\
uncomfortable \\
shovel \\
perched
\end{tabular} \\
\hline
\end{tabular}




\section{APPENDIX C. VOCABULARY SCORING RUBRIC WITH EXAMPLES FOR THE WORD "BARN"}

This rubric was modified from Justice, Meier, \& Walpole's (2005) point system and scoring protocol. Our additions are identified in italics: $0 \mathrm{~b}, 0 \mathrm{e}, \mathrm{Of}$, and $1 \mathrm{~d}$.

\section{0 - no knowledge}

Criterion

\section{Example}

a. No response

b. Inappropriate use in a phrase or an unrelated phrase or sentence (no inclusion of the word itself)

c. Inappropriate definition

d. Restatement

e. Phonological manipulation or attention to some phonological aspect

f. Multiple meaning words, gives one but not any other meaning

like jump in the swimming pool

like people sleep in

barn

barn/yarn; ball

(not applicable for the word "barn")

1 - incomplete knowledge

Criterion

\section{Example}

a. Appropriate use in phrase or sentence

your animals are in the barn/animal barn

b. Vague or imprecise definition

where you keep all the animals/where animals live

c. Imprecise synonym

d. Attributions or associations representing some knowledge of the concept

1d. Reflects research on definitions (Kurland \& Snow, 1997)

like a house

for animals/lot of pigs be at

\section{2 - complete knowledge}

\section{Criterion}

Example

a. Precise use in a phrase or sentence

b. Precise definition*

A barn is a place where animals live

* Includes use of any plausible superordinate (e.g., a dog is an animal) (Biemiller \& Boote, 2006). The inclusion of a placeholder for the superordinate was allowed (i.e., to give it definitional structure) e.g., a place where animals live. 
APPENDIX D. SAMPLE RETELLING SCORING RUBRIC FOR THE MIGHTIEST (KASZA, 2001)

Note: Scoring stops after child's response to first "Is there anything else you want to tell me?"

\begin{tabular}{|c|c|c|}
\hline Story Elements & Story Analysis & Student Response \\
\hline $\begin{array}{l}\text { Initiating Event } \\
0-1\end{array}$ & Animals found crown sitting on a rock & \\
\hline $\begin{array}{l}\text { Setting: Time and/or place } \\
0-1\end{array}$ & $\begin{array}{l}\text { Time: daytime/day } \\
\text { Place: woods/forest }\end{array}$ & \\
\hline $\begin{array}{l}\text { Characters: List the main characters and } \\
\text { character traits, if given in the story. } \\
2 \text {-animals/Old Lady/Giant } \\
1 \text {-some (Old Lady, Giant, animals) } \\
0 \text {-none }\end{array}$ & $\begin{array}{l}\text { Animals (Bear, Elephant, Lion) } \\
\text { Old Lady } \\
\text { Giant }\end{array}$ & \\
\hline $\begin{array}{l}\text { Goals: What are the goals of the main } \\
\text { characters? } \\
\text { 2-goals of two or three characters } \\
\text { 1-some goals } \\
\text {-none }\end{array}$ & $\begin{array}{l}\text { Animals (Bear, Elephant, Lion) } \\
\text { - Want to prove they are the mightiest } \\
\text { to get the crown } \\
\text { - Scare the Old Lady } \\
\text { - Want to give the crown to the Old } \\
\text { Lady } \\
\text { Giant } \\
\text { - Wants the crown } \\
\text { Old Lady } \\
\text { - Wants the Giant to stop scaring the } \\
\text { other animals }\end{array}$ & \\
\hline $\begin{array}{l}\text { Attempts: What are the attempts of the } \\
\text { main characters to reach their goals? } \\
\text { 3-seven to nine and order/all characters } \\
\text { represented } \\
\text { 2-four to six attempts/all characters } \\
\text { represented } \\
\text { 1-less than four attempts } \\
\text { 0-no attempts }\end{array}$ & $\begin{array}{l}\text { Animals } \\
\text { - Argue/decide who gets crown } \\
\text { - Try to scare the Old Lady to prove } \\
\text { they are the mightiest (Lion said } \\
\text { Roarrr, Bear said Grrrr, Elephant said } \\
\text { Barrruuu) } \\
\text { - Argue over who is the winner } \\
\text { - Animals give crown to Old Lady } \\
\text { Giant } \\
\text { - Ordered the animals to give him the } \\
\text { crown } \\
\text { - Scooped up the animals and took them } \\
\text { to drop them off the cliff } \\
\text { Old Lady } \\
\text { - Yelled at the Giant to put the creatures } \\
\text { down } \\
\text { - Puts crown back on rock }\end{array}$ & \\
\hline $\begin{array}{l}\text { Outcome: What is the story outcome? } \\
0-1 \text { accurate and at end }\end{array}$ & Walk off together & \\
\hline
\end{tabular}




\section{APPENDIX E. FOUR-DAY LESSON SEQUENCE}

\section{Day 1}

- Affirm understanding of an essential word if necessary (e.g., "school," as used in Swimmy (Lionni, 1963). Look at cover and discuss setting and characters.

- Set purpose. Example: Listen to find out what Swimmy wanted and what he did to get what he wanted.

- Read story with no attention to vocabulary (and NO PICTURES).

- After first reading aloud, return to purpose and briefly discuss.

- Teach three words (using context/sentence from the book, preplanned definitions and photos for visual support).

- Read story a second time showing PICTURES from the book.

- Set purpose: Listen for vocabulary words.

- After second reading, ask comprehension questions focused on story elements.

- Review vocabulary. (Show a photo and ask which vocabulary word describes the picture.)

\section{Day 2}

- Story review-Direct students: Turn to partner and share what you remember about the story.

- Review Day 1 vocabulary words using the photos or other context (e.g., concrete object).

- Teach three more words (see Day 1 procedures).

- Set purpose: Think about what the characters do as we retell the story with the book, because you will be acting out the story.

- Guide the students to retell the story using the pictures and integrating vocabulary words.

- Act out the story. Teacher or child is reteller/narrator and scaffolds children as they act out parts and chime in for speaking parts (i.e., words a particular character might say within the retelling. Instructor provides prompting to "actors" as needed).

\section{Day 3}

- Review all vocabulary words.

- Provide word and have students turn to partners to share definition.

- Provide a sentence prompt for students to use the word (e.g., escaped. . . I escaped from . . .).

- Review the story by discussing goals of the characters, attempts to meet their goals, and outcome. Teacher guides class to create a concise retelling of what is written on the chart.

- 5 pages of chart paper: Title page, beginning, two pages for the middle, last page for the ending.

- Integrate vocabulary words into the retelling as possible.

Before Day 4: Teacher types story into five-page facsimile of the chart for students to illustrate.

\section{Day 4}

- Review all vocabulary words.

- Provide word and have students turn to partners to share definition.

- Provide a sentence prompt for students to use the word (e.g., escaped. . . I escaped from . . .), or other "lively" review activity (Beck, McKeown, \& Kucan, 2002).

- Review the story by discussing goals of the characters, attempts to meet their goals, and outcome.

- Retell the story with book's pictures for prompts. (Teacher models first.)

- Set purpose: Retell the story in your own words and try to include the vocabulary words.

- With a partner and a copy of the book, students practice retelling the story.

- Students are directed to trade off pages as they retell the story.

- Retell with cardstock puppets. (Teacher models first and provides prompting as needed.)

- Set purpose: Retell the story in your own words and try to include the vocabulary words.

- Small groups of children retell with a set of cardstock puppets and the book for reference.

Illustrate child-sized facsimile of Day 3 chart (when schedule permits).

- Children follow along and illustrate a personal copy of the book.

- Teacher reads a page and leads discussion on what could be drawn to illustrate the page. Children illustrate. Repeat, page-by-page. 
Copyright (C) Trustees of Boston University. 